http://jmscr.igmpublication.org/home/ ISSN (e)-2347-176x ISSN (p) 2455-0450

crossref DOI: https://dx.doi.org/10.18535/jmscr/v7i10.18

\title{
To study the efficacy of vaginal misoprostol for cervical priming in first trimester MTP
}

Authors

\author{
Lalit Mahajan $^{1}$, Monika Thakur ${ }^{1 *}$, Hemender Mahajan ${ }^{2}$ \\ ${ }^{1}$ Assistant Professor, Department of Obstetrics and Gynaecology, DYSPGMC Nahan 173001 \\ Himachal Pradesh, India \\ ${ }^{2}$ Assistant Professor, Department of Obstetrics and Gynaecology, SLBSGMC Mandi 175021 \\ Himachal Pradesh, India \\ *Corresponding Author \\ Monika Thakur
}

Assistant Professor, Department of Obstetrics and Gynaecology, DYSPGMC Nahan 173001

Himachal Pradesh, India

\begin{abstract}
Background: Induced abortion medically or surgically has been practised for thousands of years. Cervical priming prior to surgical evacuation is the most important step. Among various pharmacological agents available misoprostol PGE1 analogue is the most widely used. Various routes of administration of misoprostol has own merits and demerits. The present study will determine the role of vaginal misoprostol for cervical priming in first trimester MTP.
\end{abstract}

Aims and Objectives: To study the efficacy of vaginal misoprostol for cervical priming in first trimester MTP.

Materials and Methods: One hundred and fifty women seeking MTP between 8 to 14 weeks of gestation were recruited for the study. Among these, 75 women were randomly allocated to study group which received vaginal misoprostol $400 \mu \mathrm{g} 3-4$ hours prior to surgical evacuation and 75 women were allocated to control group which underwent surgical evacuation after mechanical dilatation. The preevacuation cervical dilatation, blood loss, operative time and any complications occurred were recorded for both the groups.

Results: The mean pre evacuation cervical dilatation was significantly higher in study group in comparison to control group $(9.8 \pm 1.90 \mathrm{~mm} ; 5.45 \pm 1.23 \mathrm{~mm} ; p<0.001)$. Mean blood loss and mean time taken was significantly less in study group when compared to control group.

Conclusion: Vaginal misoprostol when used 3-4 hours prior to suction evacuation is safe, cheap, easy to use, acceptable and effective for cervical priming before dilatation.

\section{Introduction}

Induced abortion is the medical or surgical termination of pregnancy and has been practiced for thousands of years. Medical methods of abortion which include mifepristone followed by misoprostol or misoprostol alone are very popular and have decreased the rate of surgical evacuation over the time. But, still medical method is not suitable for all the cases because of continued bleeding per vaginum for longer duration and non availability of emergency services 24 hours in rural area in cases of excessive bleeding per 
vaginum. In addition, risk of treatment failure and incomplete abortion increases with advancing gestation. Therefore, Dilatation and evacuation and vaccum aspiration still remains the choice for many women. Insufficiently dilated cervix poses the risk of haemorrhage and cervical injury and increases the chances of incomplete abortion. Mechanical dilatation in unskilled hands has higher chances of injury to cervix. ${ }^{1}$ Also, cervical stenosis and incompetence has been reported with mechanical dilatation in nulliparous women as late complications. Cervical priming with various drugs has been studied in past and has shown to ease the surgical abortion by reducing the operative time, blood loss and chances of incomplete abortion. ${ }^{2,3}$ Among various pharmacological agents misoprostol PGE1 analogue which was earlier used for gastric ulcer has shown promising results. Different routes, dose and optimal timing of misoprostol has been studied in past for its optimal efficacy.

The present study was carried out to determine the role of vaginal misoprostol for cervical priming in first trimester MTP.

\section{Aims and Objective}

To see the efficacy of vaginal misoprostol for cervical priming in first trimester MTP. Secondary outcomes were to compare the intraoperative blood loss and complication rate amongst study and control groups.

\section{Materials and Methods}

This randomized controlled study was conducted at the Department of Obstetrics and Gynaecology of Indira Gandhi Medical College, Shimla. One hundred and fifty women seeking medical termination of pregnancy between 8 to 14 weeks of gestation were included in the study. Informed written consent was obtained from all the patients. Any previous history of hypersensitivity to prostaglandin, previous uterine surgery and patients with medical conditions like organic heart disease, hypertension, epilepsy were excluded. Also, if period of gestation $>14$ weeks or clinical examination revealed fever, tachycardia, jaundice or cardiac disease were excluded from the study. In cases of vaginitis or cervicitis, the procedure was postponed till ailment was treated. The patients were then randomly allocated into two groups. 75 patients were taken in study group (Group 1) in which tablet misoprostol $400 \mu \mathrm{g}$ was kept in posterior fornix 3 to 4 hours prior to medical termination of pregnancy. Another, 75 patients were taken as controls (Group 2) in which suction evacuation was done after mechanical dilatation of the cervix.

The presence of product of conception at cervical os or in the vagina before starting suction evacuation was recorded and the degree of cervical dilatation before vaccum aspiration was measured by passing Hegar's dilator through the cervix in descending order starting with no. 12 . The size of largest dilator passed into the cervical os without resistance was recorded as dilatation achieved in millimetres. Further mechanical dilatation of cervix was done depending on the size of uterus and requirement. Intraoperative blood loss was measured with the help of measuring cylinder after sieving away the products of conception. The patient was observed for 3-4 hours after suction evacuation and was discharged. Patient was advised for follow up in case of excessive bleeding per vaginum. Patients were instructed for follow up after next menstrual cycle or five weeks after the procedure whichever occur earlier. Independent t- test was applied for comparison of two groups. Proportions were compared using Chi-square of Fishers-exact test whichever was applicable.

\section{Results}

Both the groups had comparable demographic profile. [Table 1] Majority of the abortion seekers were in the age group between 20 to 30 years. The parity range was 0-5 in study group and 0-4 in control group. Main indication for termination of pregnancy was unwanted and unplanned pregnancy in $89(59.4 \%)$ women and failed contraception in $61(40.6 \%)$ women. Pre 
evacuation cervical dilatation was significantly higher in study group as compared to control group. Mean blood loss was significantly less in study group in comparison to control group. Mean operative time was also significantly less in study group. [Table 2] No cervical laceration or tear was reported in study group as compared to $5(6.67 \%)$ cervical laceration in control group and the difference was statistically significant. ( $p<0.001)$ In study group, mild vaginal bleeding was present before the procedure in 14 women (18.6\%), abdominal pain in 12 women (16\%) and product of conception at os or vagina was seen in 8 $(10.6 \%)$ patients. These side effects were mild and required no specific treatment. [Table 3]

Table 1 Demogrpahic variables

\begin{tabular}{|l|c|c|c|}
\hline Characteristics & $\begin{array}{c}\text { Study } \\
\text { group } \\
(\mathrm{n}=75)\end{array}$ & $\begin{array}{c}\text { Control } \\
\text { group } \\
(\mathrm{n}=75)\end{array}$ & $\mathrm{p}$ value \\
\hline Age & $28.08 \pm 6.6$ & $28.06 \pm 4.7$ & $>0.05$ \\
\hline Parity & $2.30 \pm 0.85$ & $2.17 \pm 0.70$ & $>0.05$ \\
\hline Gestation (in weeks) & $9.55 \pm 1.53$ & $9.43 \pm 1.38$ & $>0.05$ \\
\hline
\end{tabular}

Table 2 Introperative findings

\begin{tabular}{|l|c|c|c|}
\hline Characteristics & $\begin{array}{c}\text { Study } \\
\text { group } \\
(\mathrm{n}=75)\end{array}$ & $\begin{array}{c}\text { Control } \\
\text { group } \\
(\mathrm{n}=75)\end{array}$ & $\mathrm{p}$ value \\
\hline Pre evacuation & $9.18 \pm$ & $5.45 \pm 1.23$ & $<0.001^{*}$ \\
cervical dilatation & 1.90 & & \\
\hline $\begin{array}{l}\text { operative time } \\
\text { (min) }\end{array}$ & $5.79 \pm$ & $7.65 \pm 2.33$ & $<0.01^{*}$ \\
\hline Intraoperative & $56.10 \pm$ & $75.00 \pm$ & $<0.01^{*}$ \\
blood loss & 19.40 & 16.00 & \\
\hline
\end{tabular}

*P value significant

Table 3 Incidence of Complications

\begin{tabular}{|l|c|c|c|}
\hline Characteristics & $\begin{array}{c}\text { Study } \\
\text { group } \\
(\mathrm{n}=75)\end{array}$ & $\begin{array}{c}\text { Control } \\
\text { group } \\
(\mathrm{n}=75)\end{array}$ & p value \\
\hline $\begin{array}{l}\text { Cervical } \\
\text { Laceration }\end{array}$ & Nil (0\%) & $5(6.67 \%)$ & $<0.001^{*}$ \\
\hline $\begin{array}{l}\text { Nausea and } \\
\text { Vomiting }\end{array}$ & $1(1.3 \%)$ & Nil & \\
\hline Diarrhoea & $1(1.3 \%)$ & Nil & \\
\hline $\begin{array}{l}\text { Lower abdominal } \\
\text { pain }\end{array}$ & $12(16 \%)$ & Nil & \\
\hline Vaginal Bleeding & $14(18.67 \%)$ & Nil & \\
\hline
\end{tabular}

*P value significant

\section{Discussion}

Various studies in past has proven the role of misoprostol as an effective cervical priming agent prior to surgical evacuation. ${ }^{4,5}$ The various routes of misoprostol administration have been studied with respect to efficacy and side effect profile in the past. The studies comparing oral and vaginal misoprostol in the past has shown vaginal route to be more effective for pre evacuation cervical dilatation. $^{4,5,6}$ In contrast, a study on pharmacokinetics of misoprostol quote sublingual route to be a better alternative because of rapid bioavailability and highest peak concentration achieved with this route. ${ }^{7}$ Oral or sublingual misoprostol is easy to administer and avoids the discomfort which happens during vaginal insertion of tablet. Still, vaginal route remains the preferred choice for many because it avoids the systemic side effects and slow consistent absorption from the vaginal mucosa improves the rates of cervical priming. Our study further adds to the fact that vaginal route of misoprostol is effective for cervical ripening prior to surgical abortion.

In present study, mean cervical dilatation was 9.18 $\pm 1.90 \mathrm{~mm}$ in study group with range from 6 to 12 $\mathrm{mm}$ and in control group it was $5.45 \pm 1.23 \mathrm{~mm}$ with range from 4 to $8 \mathrm{~mm}$, which was statistically highly significant. $(p<0.001)$ The findings were consistent with study done by Gupta et $\mathrm{al}^{8}$ which observed mean cervical dilatation of $9.26 \pm 1.72 \mathrm{~mm}$ in study group and $4.28 \pm 1.3 \mathrm{~mm}$ in control group. The mean blood loss in the study group was $56 \pm 19.40 \mathrm{ml}$ versus control group which observed mean blood loss to be $75 \pm 16 \mathrm{ml}$. The difference was significant statistically. ( $p$ $<0.01$ ) Fong et $\mathrm{al}^{9}$ reported $97.5 \pm 19.2 \mathrm{ml}$ blood loss, Singh et $\mathrm{al}^{4}$ had mean blood loss of $88.5 \pm$ $3.5 \mathrm{ml}$ and Ngai et al ${ }^{10}$ reported mean blood loss of $57 \mathrm{ml}$ in their study group which was comparable with our study. Kaur et $\mathrm{al}^{11}$ reported blood loss of $54.07 \mathrm{ml}$ which was similar to our study. The mean time taken for procedure in our study group was $5.79 \pm 1.85$ minutes as compared to $7.65 \pm 2.33$ minutes in control group which was statistically significant. ( $\mathrm{p}<0.01)$ Ngai et $\mathrm{al}^{10}$ found no significant difference in time taken for procedure in their study group $(4.9 \pm 1.9$ minute $)$ as compared to control group ( $4.9 \pm 2.1$ minute) . 
Our results are comparable to those of Gupta et $\mathrm{al}^{8}$ who reported significant difference in time taken for the procedure in their study group $(4.61 \pm 0.31$ minutes) as compared to control group (5.96 \pm 0.61 minutes) with $\mathrm{p}<0.001$.

No cervical injury was observed in the study group while there was $6.6 \%$ cases of cervical injury due to forceful dilatation in control group and the difference was statistically significant ( $p$ $<0.001$ ). Similar results were observed by Gupta et $\mathrm{al}^{8}$ where $4 \%$ uterine perforation and $4 \%$ cervical injury were reported in control group with none in study group. In study group, mild vaginal bleeding was present before the procedure in 14 women $(18.6 \%)$, abdominal pain in $12(16 \%)$ women and products of conception at os or vagina seen in $8(10.6 \%)$ patients. Diarrhoea and nausea was observed in one woman each. These side effects were mild and required no specific treatment. The side effect profile reported was similar to study conducted by Gupta et $\mathrm{al}^{8}$, Singh et $\mathrm{al}^{4}$ and Kaur et $\mathrm{al}^{11}$. Sixty (80\%) of patients in study group and $56(76 \%)$ of patients in control group who came for follow up had no complications.

\section{Conclusion}

The results of the present study suggest that use of $400 \mu \mathrm{g}$ misoprostol intravaginally, 3-4 hours prior to suction evacuation is safe, cheap, easy to use and effective for cervical priming before dilatation. It reduces the duration of procedure, blood loss and also the risk of cervical or uterine injury.

Conflict of Interest: The authors report no conflict of interest.

Financial Resources: No funding sources

\section{References}

1. Molin A. Risk of damage to the cervix by dilatation for first trimester- induced abortion by suction aspiration. Gynecol Obstet Invest. 1993;35(3):152-54.
2. World Health Organization. Safe Abortion: Technical and Policy Guidance for Health Systems. Geneva: WHO; 2003.

3. Royal College of Obstetricians and Gynaecologists. The care of women requesting induced abortion, Evidencebased Clinical Guideline, Number 7. London: RCOG; 2004.

4. Singh K, Fong YF, Prasad RN, Dong F. Vaginal misoprostol for preabortion cervical priming: is there an optimal evacuation time interval? $\mathrm{Br} \mathrm{J}$ Obstet Gynaecol. 1999;106(3):266-69.

5. Ngai SW, Tang OS, Lao T, Ho PC, Ma HK. Oral misoprostol versus placebo for cervical dilatation before vacuum aspiration in first trimester pregnancy. Hum Reprod. 1995;10(5):1220-22.

6. Cakir L, Dilbaz B, Caliskan E, Dede FS, Dilbaz S, Haberal A. Comparison of oral and vaginal misoprostol for cervical ripening before manual vacuum aspiration of first trimester pregnancy under local anesthesia: a randomized placebocontrolled study. Contraception. 2005;71:337-42.

7. Tang OS, Schweer H, Seyberth NW, et al. Pharmacokinetics of different routes of administration of misoprostol. Hum Reprod. 2002;17:332-36.

8. Gupta A and Anita. Efficacy of misoprostol for cervical priming before dilatation in first trimester MTP. J Obstet \& Gynecol of India 2002;52(5):54-56.

9. Fong YF, Singh K, Prasad RNV. A comparative study using two dose regimens of vaginal misoprostol for preoperative cervical dilatation in first trimester nulliparae. Brit J Obstet \& Gynaecol 1998;105:413-17.

10. Ngai SW, Yeung KCA, Lao T et al. Oral misoprostol versus mifepristone for cervical dilatation vaccum aspiration in first trimester nulliparous pregnancy : a double blind prospective randomized 
study. Brit J Obstet \& Gynaecol 1996;103:1120-23.

11. Kaur D, Kaur H and Gupta S. Misoprostol - A cervical ripening agent in first trimester abortions. J Obstet Gynecol Ind 2003;53(5):482-84. 